Women and Minorities

Improving the Status of Women in Political Science: A Final

Report with Recommendations

1992 Ralph Bunche Summer Institute

Committee on the Status of Blacks Honors Former APSA

Graduate Fellows

APSA Bunche Students Attend Annual Meeting

Participation by Women in the 1992 APSA Meeting

APSA Minority Graduate Fellows Selected
September $1992 \quad 547$

September $1992 \quad 607$

December $1992 \quad 761$

December $1992 \quad 762$

March $1993 \quad 107$

June $1993 \quad 277$

\section{APSA Council Reviews the Credential Referral Service}

At its April 17, 1993 meeting, APSA's Council reviewed the Credential Referral Service, with the following three facts in mind:

- fewer than 2\% of APSA's members use this service;

- the expense to APSA greatly exceeds the fees charged for this service; and

- many people who use the Credential Referral Service have alternatives, but not everyone does.

Balancing a concern for fiscal responsibility with a desire to help job applicants, the Council decided to retain the Credential Referral Service but to limit its scope and to require users to pay much more, but not all, of the cost of running this program.

Specifically, only those members earning $\$ 40,000$ or less are eligible for the service. The fee to enroll is now $\$ 100$ rather than $\$ 25$. This covers four referrals per month. Any referrals above four cost $\$ 10$ each. As in the past, participants must be current members of APSA and subscribers to the Personnel Service Newsletter.

Those members who are eligible and desire to enroll will need to submit $\$ 100$ rather than $\$ 25$. For current members of the service, the old rules apply until the subscription year is complete.

In a related matter the Council reaffirmed its policy of confidentiality for all letters of reference. Should APSA be notified by an institution that it cannot maintain such confidentiality - because of state open document laws or other reasons-our policy will be to withdraw the file and notify the applicant that this has occurred.

Questions about the new procedures should be directed to the
Credential Referral Service at (202) 483-2512, or 1527 New Hampshire Avenue, NW, Washington, DC 20036.

\section{APSA Extends Family Memberships to Include Domestic Partners}

Domestic partners of Association members are now eligible to join APSA under family memberships. The Administrative Committee of the APSA Council has affirmed the principle that all APSA programs that are available to spouses of members be available to domestic partners of members, which has led to the extension of the family membership option. The Committee on the Status of Lesbians and Gays in the Profession and APSA staff are now exploring other implications of this principle across all APSA activities. Any member with ideas, suggestions, or comments are invited to send comments to Mark Blasius, chair of the Committee, at APSA, 1527 New Hampshire Avenue, NW, Washington, DC 20036.

In principle, a domestic partnership, for purposes of APSA family membership, is defined as two individuals who live in a relationship similar to marriage, who are not married to anyone else, and who agree to be responsible for each other's welfare and to share financial obligations. Further reports on the implementation of this benefit and related policies will be made in subsequent issues of $P S$.

\section{Committee on Professional Ethics, Rights and Freedoms}

The following report provides an overview of the work of the Commit- tee on Professional Ethics, Rights and Freedoms. The Committee is available to address individual complaints about violations of ethical standards of the discipline, as well as to work with political scientists, departments, and other institutions in advancing professional standards as articulated in the APSA Guide to Professional Ethics in Political Science.

The Guide to Professional Ethics in Political Science was reprinted in the June 1992 issue of PS. It is mailed to all departments participating in the APSA Departmental Services Program, and is sent free of charge to all senior doctoral students. Members can order a copy from APSA for $\$ 4.00$ plus $\$ 1.00$ shipping and handling for single copies.

Members of the Committee welcome hearing from political scientists about matters of practice and policy. All inquiries are handled in confidence. The Committee presently is chaired by John J. DiIulio, Jr., Princeton University. Other members are Seyom Brown, Brandeis University; Jean Elshtain, Vanderbilt University; Armin Rosencranz, Pacific Energy and Resources Center; and Joseph Silver, University System of Georgia. Correspondence to the Committee should be sent to the Chair, care of APSA, 1527 New Hampshire Avenue, NW, Washington, DC 20036; and inquiries can be directed to Michael Brintnall at APSA by phone (202) 483-2512, Fax (202) 483-2657, and E-mail, incem024@sivm.

\section{The Committee on Professional Ethics, Rights and Freedoms Overview and Status Report}

\section{Alys Brehio and Michael Brintnall, American Political Science Association}

The APSA Committee on Professional Ethics, Rights and Freedoms has been in place since 1968, when it was formed following recommendations of a Council designated task force chaired by Marver Bernstein. This report provides a brief overview of the work of the committee and of the issues that it faces.

The work of the Committee is intertwined with the Association's Guide to Professional Ethics in Polit- 